WIDER Working Paper 2017/166

\title{
Breaking the metal ceiling
}

Female entrepreneurs who succeed in male-dominated sectors

Francisco Campos, ${ }^{1}$ Markus Goldstein, ${ }^{2}$ Laura McGorman, ${ }^{3}$ Ana Maria Munoz Boudet, ${ }^{4}$ and Obert Pimhidzai ${ }^{5}$

September 2017 
Abstract: Occupational segregation significantly contributes to the earnings gender gap worldwide. We look at differences in outcomes for male and female enterprises and their sectors in Sub-Saharan Africa, a region of high female participation in entrepreneurship. Data on Uganda show that women breaking into male-dominated sectors make as much as men, and three times more than women staying in female-dominated sectors. Factors including entrepreneurial skill/abilities and credit/human capital constraints do not explain women's sectoral choices. However, information about profitability, male role models' influence, and exposure to the sector from family and friends are critical in helping women circumvent or overcome norms undergirding occupational segregation.

Keywords: gender; norms; labour market participation; entrepreneurship; small enterprises JEL classification: J16, O17, O12, D22, D24, L25, L26

Acknowledgements: We thank the UN Foundation for financial support for this project. We also thank the World Bank's Bank-Netherlands Partnership Program Trust Fund and Belgium Poverty Reduction Program for financial support for the impact evaluation project on which the project draws. We thank Elena Bardasi and Mayra Buvinic for helpful comments and guidance, and participants in seminars at the World Bank and the UN Foundation for comments. We would also like to thank Victoria Katende of Makerere University for the excellent work in leading the logistics and implementation of the qualitative assessments, and Nelson Matua for his support in supervising face-to-face interviews. This work has been funded in part by the Umbrella Facility for Gender Equality (UFGE), a World Bank Group multi-donor trust fund expanding evidence, knowledge, and data needed to identify and address key gaps between men and women to deliver better development solutions that boost prosperity and increase opportunity for all. The UFGE has received generous contributions from Australia, Canada, Denmark, Finland, Germany, Iceland, the Netherlands, Norway, Spain, Sweden, Switzerland, the United Kingdom, and the United States.

\footnotetext{
1 World Bank Group, Mozambique; 2 World Bank Group, Washington, DC, USA, corresponding author: mgoldstein@worldbank.org; ${ }^{3}$ John F. Kennedy School of Government, Harvard University, Cambridge, MA, USA; ${ }^{4}$ World Bank Group, Washington, DC, USA; 5 World Bank Group, Wasington, DC, USA.
}

This study is reproduced with World Bank permission within the UNU-WIDER project on 'Gender and development'.

Copyright (C) by International Bank for Reconstruction and Development/World Bank 2017

Information and requests: publications@wider.unu.edu

ISSN 1798-7237 ISBN 978-92-9256-392-9 https://doi.org/10.35188/UNU-WIDER/2017/392-9

Typescript prepared by Luke Finley.

The United Nations University World Institute for Development Economics Research provides economic analysis and policy advice with the aim of promoting sustainable and equitable development. The Institute began operations in 1985 in Helsinki, Finland, as the first research and training centre of the United Nations University. Today it is a unique blend of think tank, research institute, and UN agency—providing a range of services from policy advice to governments as well as freely available original research.

The Institute is funded through income from an endowment fund with additional contributions to its work programme from Denmark, Finland, Sweden, and the United Kingdom.

Katajanokanlaituri 6 B, 00160 Helsinki, Finland

The findings, interpretations, and conclusions expressed in this paper are entirely those of the authors. They do not necessarily represent the views of the International Bank for Reconstruction and Development/World Bank and its affiliated organizations, those of the Executive Directors of the World Bank or the governments they represent, or those of the Institute or the United Nations University or the programme/project donors. 
Evidence from developed and developing countries indicates that there is significant gender segregation within the labour market, with women more likely to work in low-productivity sectors or less profitable businesses, or be relegated to unpaid family employment or the informal wage sector (Dolado et al. 2003; ILO 2012; World Bank 2011). In entrepreneurship, women-owned ${ }^{1}$ businesses typically underperform compared to men's (see Klapper and Parker, 2011, for an overview of this literature). While female participation in entrepreneurial activities varies by region, the gaps in productivity and growth between male- and female-owned enterprises are stark and remain large even in rich countries (Klapper and Parker 2011; World Bank 2011). Occupational segregation also comes with a growth cost. If we make the not unreasonable assumption that skills are equally distributed across men and women at the start, the growth of an economy will be reduced by gender segregation of employment, as a given sector will not have access to the full set of skills that exist. Focusing on enterprises in developing countries, Bruhn (2009) finds that femaleowned firms throughout Latin America tend to be smaller than male-owned firms in terms of sales, number of employees, and profits. Similarly, Bardasi et al.(2011) reveal large gaps in firm size in Europe and Central Asia, Latin America, and Sub-Saharan Africa. And research in Latin America and Asia finds that only one in ten firms growing to at least 15 employees is womenowned (Kantis et al. 2005).

In Africa, female participation in entrepreneurial activities is higher than in any other region, with women representing half of non-farm business ownership (Hallward-Driemeier 2011). However, these entrepreneurship opportunities have yet to lead to equal earnings between women and men. A range of studies show female-owned firms lagging behind their male counterparts in a number of key measures of enterprise performance. In terms of revenue, Bardasi et al. (2011) indicate that female-owned enterprises in Sub-Saharan Africa have sales that are 31 per cent lower than those of male-owned firms. For productivity, Hallward-Driemeier (2011) estimates the gender gaps in labour productivity in Africa to be 6 to 8 per cent, and Rijkers and Costa (2012) analyse rural nonfarm entrepreneurship and find that male-owned firms in Ethiopia are three times more productive than female-owned ones. Finally, our examination of summary statistics from the Uganda National Household Survey 2005/06 (UBOS 2006) indicates that male-owned businesses in Uganda are 3.1 times larger than female-owned enterprises and earn 2.5 times as much.

A range of factors have been discussed in the literature to explain these differences (Klapper and Parker 2011; World Bank 2011), including access to finance and time constraints. However, the sector in which the firm operates is consistently found to be a major determinant of gender-related differences in performance and growth (e.g. Bardasi et al. 2011; Hallward-Driemeier 2011; Rijkers and Costa 2012). ${ }^{2}$ For example, Hundley (2001) estimates that women's concentration in the personal services sector explains as much as 14 per cent of the gender-based self-employment earnings differential. De Mel et al. (2009) find that female ownership loses statistical significance in explaining differences in performance once industry choice is controlled for. Results from

\footnotetext{
${ }^{1}$ See Aterido and Hallward-Driemeier (2011) for a discussion on the importance of the definition of female ownership between partial ownership and decision-making. In the setting of this study 90 per cent of the enterprises have only one owner. For those in partnership, female ownership is defined in this study as the main business owner being a woman.

2 A survey of developed-country literature on small and medium firms suggests that the limited growth observed among female-owned firms is due to the over-representation of women in a subset of sectors (Nichter and Goldmarck 2009).
} 
Guatemala (Kevane and Wydick 2001) and India (Kantor 2005) suggest that constraints on femaleowned firms and their sector concentration respond to factors such as the marginal value of time for home production, and constraints on location of business, among others. ${ }^{3}$

Differences in sectoral choice between men and women are large, with the vast majority of female entrepreneurs clustering in low-value-added industries. Women entrepreneurs in Africa tend to concentrate in hotels and restaurants, wholesale and retail trade, garments, textiles and leather goods, and other services (Bardasi et al. 2011). African men, on the other hand, have businesses distributed across a wider range of sectors, including construction and manufacturing.

Given that existing research has identified industry concentration as important in determining future profitability and growth, the current debate is centred on whether the women's decision to enter these sectors is driven by constraints or preferences (see Bardasi et al., 2011, for an overview of this literature). Hasan et al. (2011) suggest that there are some behavioural and perception-based determinants of lower profitability, namely that female entrepreneurs exhibit a significant amount of 'intrinsic' rather than 'extrinsic' motivation, and are often driven more by flexible work schedules or personal achievement than by a raw interest in profit or growth, contributing to preference-driven hypotheses. Similarly, Minniti (2010), among others, suggests that female entrepreneurs exhibit less confidence than men in their skill sets and ability to take risks. Conversely, research in Africa (for instance Bardasi and Getahun 2008) and elsewhere (Brush 1992) has found that women are often constrained by a range of factors, including limited access to finance and human capital development opportunities, which points more to a constraint-driven hypothesis.

Given that reducing occupational segregation could increase economic efficiency and help to close the female-male gap in earnings, we look at what factors help or hinder women in moving into male-dominated trades. ${ }^{4}$ We do this in the context of Uganda, which shows the concentration pattern that the studies above refer to: only 6 per cent of women operate in male-dominated sectors $^{5}$ (where over 75 per cent of enterprises are male-owned ${ }^{6}$ ), while 34 per cent of men have businesses in those industries (UBOS 2006). In order to better understand which factors might matter, we break variables into three analytical groups.

First, we look at whether the crossover entrepreneurs (women who own businesses in maledominated industries) are above average in their entrepreneurial skill or abilities. Second, we

\footnotetext{
${ }^{3}$ Kantor (2005) shows that 36 per cent of female entrepreneurs operate home-based firms, where clients go to them for purchases, compared to 20 per cent of male entrepreneurs. Household firms are smaller, and also less likely to grow (Mead and Liedholm 1998).

${ }^{4}$ Of course, efficiency would also be helped by examining the factors that help or hinder men in moving into femaledominated industries. This would be an interesting question for future research.

${ }^{5}$ While in the literature male-dominated sectors are often defined as those where more than 50 per cent of the firms are male-owned (over-representation), in this study we focus on enterprises where male domination is over 75 per cent, because the over-representation in other data could just be a reflection of the specific sample, which is often not representative of the population-eg: the World Bank/International Finance Corporation Enterprise Surveys are often not representative of the population of firms in a country (given the absence of a solid census of firms). While these classifications at the margin could potentially average out in a quantitative analysis, they matter considerably when looking at a qualitative assessment, which is why we adopt the more conservative definition here.

${ }^{6}$ Of course, if more women were to operate in those sectors, they would cease to be male-dominated, but currently, and over time and across countries, the pattern is prevalent, and hence important to analyse.
} 
examine the possibility that their psychosocial ${ }^{7}$ development explains their ability to overcome occupational segregation. Finally, as credit and human capital constraints are often cited as factors that hold back women's businesses no matter which sector they are in, we examine the possibility that the ability to overcome these constraints might explain their presence in these non-traditional sectors.

We use a mixed-methods approach to examine these potential explanations. We find, first, that women who cross over into male-dominated sectors make as much as men, and more than women who stay in female-dominated sectors. But this fact is unknown to a majority of the women who do not cross over, suggesting information is a key initial hurdle to crossing over. The main factors that seem to be associated with crossing over are psychosocial—particularly the influence of male role models and exposure to the sector from family and friends. These factors are likely to be critical in helping the crossover women circumvent or overcome the norms that undergird occupational segregation. On the other hand, capital and skills are not significantly correlated with the likelihood that a woman operates a business in a male-dominated sector.

The next section lays out the data we use and the methods by which they were collected. After exploring the characteristics of female-owned firms in our study sample, and comparing them with male-owned firms in terms of productivity and profits (Section 3), we move on to examine the relative roles of the three groups of factors mentioned above in determining which women cross over and which do not (Section 4). Once in business, challenges such as access to finance, lack of networks, and sometimes a hostile environment are the most prevalent ones, together with limited technical and managerial skills_ - as detailed in Section 5. Section 6 draws on the findings to identify some areas for testing future policy interventions aiming to promote female participation in maledominated sectors of the economy, as well as to support women who wish to cross over.

\section{Data and methods}

This paper draws on baseline data collected in 2011 from a sample of entrepreneurs in urban Uganda from within and just outside Kampala, which are mostly part of the Katwe Small Scale Industry Association (KASSIDA). The data were collected as part of an evaluation of the impact of a skills and managerial training programme on business performance. The baseline survey included a total sample of 326 women and 409 men, of which only 30 women (crossovers) owned businesses in male-dominated sectors. Table 1 shows the distribution of women and men across different industries and indicates the gender concentration, with crossover sectors identified in bold. We use this data set (hereafter the KASSIDA data set), which has detailed information on assets, inputs, other costs, sales, and profits, to compare the performance of crossovers with both other women-owned businesses in traditional female sectors and male-owned businesses in the same sectors.

\footnotetext{
${ }^{7}$ Here we use the definition of psychosocial as the interrelation between social and individual factors expressed in someone's behaviours and mind.
} 
Table 1: Number of enterprises per sector in the KASSIDA data set

\begin{tabular}{|l|c|c|c|}
\hline & \multicolumn{2}{|c|}{ Female-owned } & Male-owned \\
\hline Sector & Crossovers & Non-crossovers & \\
\hline Barbershop/hair salon & 0 & 63 & 7 \\
\hline Carpentry & 4 & 0 & 44 \\
\hline Catering & 0 & 107 & 2 \\
\hline Electricals & 1 & 0 & 11 \\
\hline Fitting and machinery & 0 & 0 & 11 \\
\hline Foundry and forgery* & 15 & 0 & 48 \\
\hline Metal fabrication & 7 & 0 & 185 \\
\hline Shoe making and repair & 3 & 0 & 33 \\
\hline Tailoring/knitting & 0 & 126 & 68 \\
\hline Total & 30 & 296 & 409 \\
\hline
\end{tabular}

Notes: * Forgery could be integrated into metal fabrication under a different definition of sectors. The definition used follows the list of sectors identified by KASSIDA to organize their work.

The sample size in Table 1 is larger than in the analysis that follows as we do not observe all variables for all firms listed here.

Source: Authors' own construction.

We also use the outcomes of a mixed-methods questionnaire collected uniquely for this paper (hereafter the mixed-methods data set). This questionnaire was administered in July/August 2012 to 187 female entrepreneurs - 67 working in male-dominated sectors such as those identified in Table 1, and 120 working in traditionally female sectors (catering, hairdressing, and tailoring) (see Table 2).

Table 2: Number of enterprises per sector in the mixed-methods data set

\begin{tabular}{lcc} 
& \multicolumn{2}{c}{ Female-owned } \\
Sector & Crossovers & Non-crossovers \\
Carpentry & 26 & 0 \\
Catering & 0 & 41 \\
Clay moulding & 0 & 1 \\
Electricals & 1 & 0 \\
Fitting and machinery & 7 & 0 \\
Foundry and forgery & 15 & 0 \\
Hair salon & 0 & 23 \\
Metal fabrication & 10 & 0 \\
Shoe making and repair & $\mathbf{8}$ & 0 \\
Tailoring/knitting & 0 & 55 \\
Total & 67 & 120 \\
\hline
\end{tabular}

Source: Authors' own construction. 
As the study was designed to include both formal and informal businesses, it is not representative of all enterprises in Kampala. ${ }^{8}$ Instead, for the mixed-methods data set, an initial sample of crossover respondents was drawn from the KASSIDA data set (21 in all) and complemented by additional crossover participants identified through snowball sampling. For non-crossovers, 60 respondents were identified through a random sample of the KASSIDA data set, ${ }^{9}$ and an additional 60 were matched to the crossover sample on a small list of pre-business characteristics. ${ }^{10}$ Given the mixed methods and not purely quantitative approach, the objective of the matched subset was to enable a sufficient sample of individuals with characteristics relatively similar to crossovers before the inception of their business, with the main difference being that they took different paths due to a set of factors to be explained in the analysis.

We prepared semi-structured interview instruments to capture a wide range of information about female entrepreneurs, including their background, family history, education, entrepreneurial capacity/tendency (risk aversion, ${ }^{11}$ personality profile, IQ), access to networks, presence of role models, and a host of other factors. In addition to these quantitative measures, there were openended questions that allowed participants to supply answers in their own words and elaborate on the path that led them to be in a specific business sector. The instruments included substantial room for probing by enumerators, leading to a rich quantitative and qualitative data set. ${ }^{12}$

To complement the information obtained in individual interviews, we conducted 17 focus group discussions with crossovers, non-crossovers, clients, suppliers, and (male) employees, with approximately six members per group. Focus groups of entrepreneurs included cases where only one sector was represented, as well as others that included a mix of both crossovers and noncrossovers. Additionally, we interviewed a set of community leaders and credit providers to gauge the structural constraints facing both female entrepreneurs in male-dominated sectors, and those in female-dominated sectors. Including various actors in the business and community environments allows us to better measure community-wide perceptions on female participation in entrepreneurial activities, enabling a better understanding of why so few female entrepreneurs decide to cross over.

\section{The profitability and productivity of male- and female-owned firms}

In this section, we investigate the differences in size and firm-level performance between firms owned by women crossovers and non-crossovers, as well as between crossover firms and those owned by men operating in the same sectors. We use the KASSIDA data set (discussed above) to document these differences and examine to what extent the differences are explained by production inputs and the scale of the operation.

\footnotetext{
${ }^{8}$ The inclusion of informal businesses results in the lack of an accessible sample frame from which to draw.

${ }^{9}$ Respondents from the KASSIDA data set included members of both the treatment and the control groups, the former of which had received technical and managerial training, the latter of which had not.

${ }^{10}$ These characteristics included nearest neighbour on age, age squared, and completion of primary education.

${ }^{11}$ The games on risk aversion were not considered for this analysis because, half-way through implementation, survey audits indicated problems in administering this part of the survey.

${ }^{12}$ Interviews were recorded and there was space in the questionnaire for additional writing of questions and answers.
} 
The place to start with this examination is the profits of different firms. Looking within femaleowned firms, Figure 1 shows the distribution of the logarithm of monthly profits for crossovers versus non-crossovers. As per the literature on the importance of sectors in explaining gender gaps (Bardasi et al. 2011; Klapper and Parker 2011), many of the women who cross over make higher profits than women who do not.

Figure 1: Distribution of (log) monthly profits for women crossovers and non-crossovers-KASSIDA data set

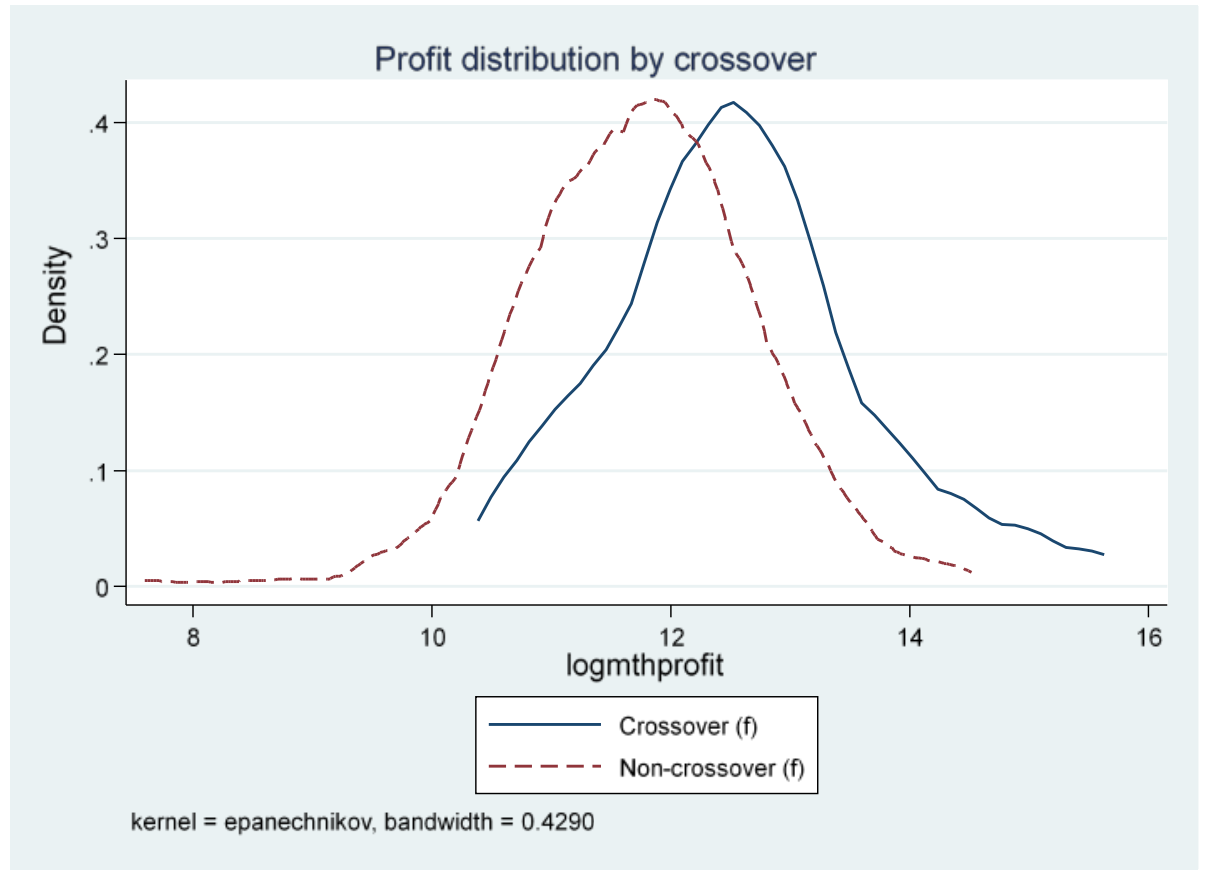

Source: Authors' own construction.

In Figure 2, we examine the relative profits of female crossover firms versus male-owned firms in the same sectors. This figure shows distributions of profit that are a lot more similar than those in Figure 1, indicating that businesses owned by women that cross over to male-dominated sectors perform similarly to male-owned businesses in those sectors. 
Figure 2: Distribution of $(\log )$ monthly profits for women crossovers and men in same sectors—KASSIDA data set

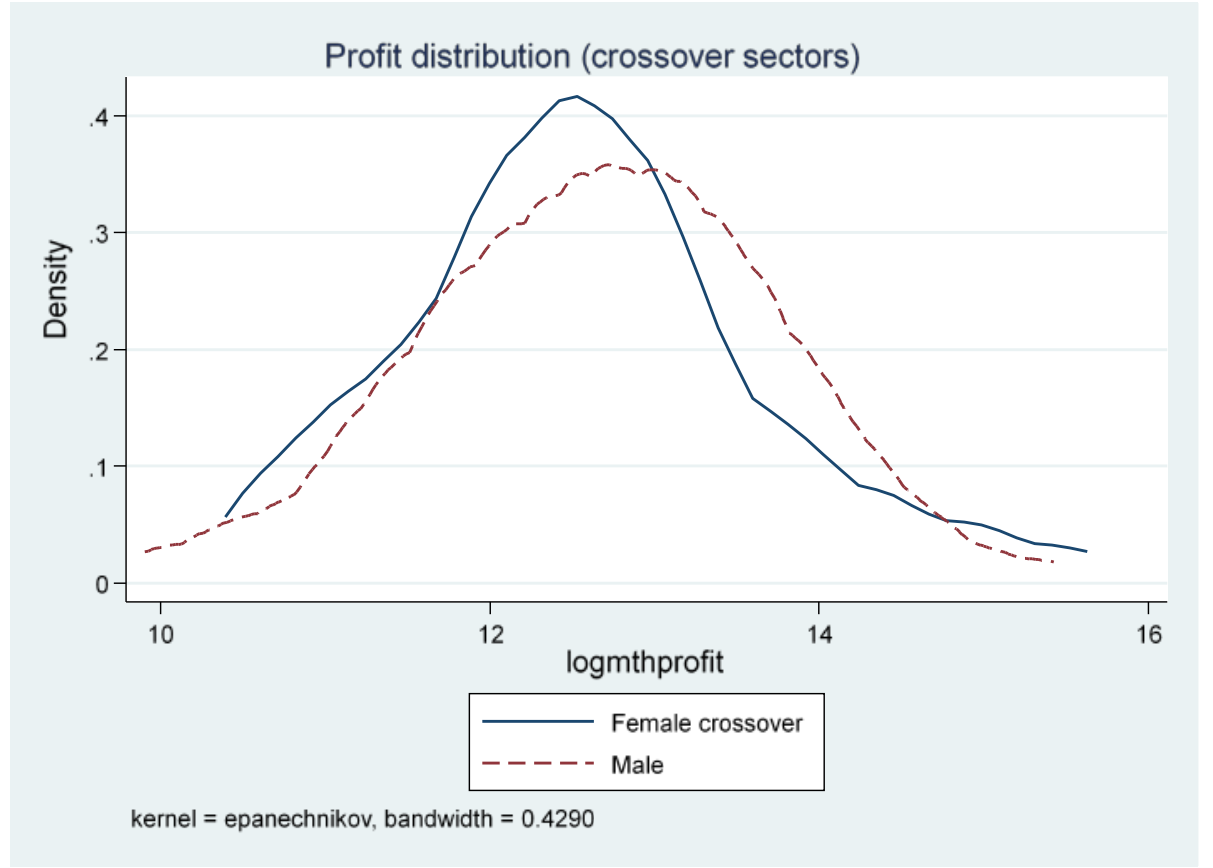

Source: Authors' own construction.

In order to examine the differences between women who cross over and those who do not in more depth, we now turn to a set of basic statistics in Table 3 . 
Table 3: Summary statistics for female-owned enterprises-KASSIDA data set

\begin{tabular}{|c|c|c|c|c|c|}
\hline & Total & StDev & Crossover & Non-crossover & Difference \\
\hline \multicolumn{6}{|l|}{ Financials } \\
\hline Revenues past month (UGX '000) & 1,058 & 2,246 & 2,697 & 914 & $1,783^{\star \star \star}$ \\
\hline Profits past month (UGX '000) & 229 & 392 & 494 & 205 & 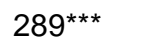 \\
\hline \multicolumn{6}{|l|}{ Investment } \\
\hline Net capital invested (UGX ‘000) & 2,056 & 5,880 & 5,312 & 1,769 & $3,543^{\star \star \star}$ \\
\hline Number of workers & 2.6 & 2.0 & 3.9 & 2.4 & $1.5^{\star \star \star}$ \\
\hline Inputs consumed past month (UGX '000) & 377 & 783 & 968 & 325 & $643^{\star \star \star}$ \\
\hline \multicolumn{6}{|l|}{ Personal characteristics } \\
\hline Age & 37 & 9 & 42 & 36 & $6^{\star \star *}$ \\
\hline Married & 53 & 50 & 40 & 54 & -14 \\
\hline Widow & 13 & 34 & 32 & 11 & $21^{\star \star \star}$ \\
\hline Less than primary education & 12 & 32 & 30 & 10 & $20 * \star \star$ \\
\hline Primary school is max. education & 52 & 50 & 26 & 54 & $-28^{\star \star \star}$ \\
\hline Secondary school is max. education & 24 & 43 & 30 & 24 & 7 \\
\hline Completed more than secondary & 13 & 33 & 13 & 13 & 0 \\
\hline Previously worker in sector & 13 & 33 & 12 & 13 & -1 \\
\hline Received business or technical training in past & 43 & 50 & 72 & 40 & $32^{\star \star *}$ \\
\hline Financial literacy index (0-1) & 0.5 & 0.1 & 0.5 & 0.4 & $0.1^{\star \star \star}$ \\
\hline Technical literacy index (0-1) & 0.4 & 0.2 & 0.4 & 0.4 & 0.0 \\
\hline Owns more than one business & 15 & 36 & 24 & 14 & 10 \\
\hline Household and business activities simultaneously & 30 & 46 & 44 & 29 & 15 \\
\hline \multicolumn{6}{|l|}{ Business characteristics } \\
\hline Business owner started this firm & 93 & 26 & 84 & 93 & $-9 *$ \\
\hline Saw market opportunity when starting business & 56 & 50 & 48 & 57 & -9 \\
\hline Has business partners & 3 & 16 & 0 & 3 & -3 \\
\hline Business is registered & 46 & 50 & 44 & 46 & -2 \\
\hline Age of business & 9 & 7 & 14 & 9 & $5^{\star \star \star *}$ \\
\hline Size of business network (log) & 3.2 & 1.1 & 3.4 & 3.1 & 0.2 \\
\hline \multicolumn{6}{|l|}{ Access to finance } \\
\hline Has bank account & 51 & 50 & 60 & 50 & 10 \\
\hline Has received business support & 14 & 18 & 19 & 13 & $6^{*}$ \\
\hline Belongs to SACCO & 18 & 39 & 32 & 17 & $15^{\star}$ \\
\hline Has received loan & 32 & 47 & 44 & 31 & 13 \\
\hline \multicolumn{6}{|l|}{ Harassment (past 12 months) } \\
\hline Has been sexually harassed & 16 & 37 & 8 & 17 & -9 \\
\hline Other type of harassment ${ }^{+}$ & 42 & 49 & 40 & 42 & -2 \\
\hline $\mathrm{N}$ & 309 & & 25 & 284 & \\
\hline
\end{tabular}

Notes: ${ }^{\star * *} p<0.01,{ }^{* \star} p<0.05,{ }^{*} p<0.1$. At the time of the survey, 1 US $\$=$ UGX 2,250. 


\begin{abstract}
+ other type of harassment includes: threats to shut down business; shouting, scolding, making a nuisance in or near enterprise premises; vandalism of premises or merchandise; confiscation of property or merchandise; pushing or shoving; and beating.
\end{abstract}

Source: Authors' own construction.

Table 3 shows the vast difference across these two types of female entrepreneurs and their firms. First of all, we can see that the average revenue of a crossover firm is about three times that of a non-crossover firm, and profit is more than double. In addition, as might be expected, the crossover firms operate at a larger scale, with significantly higher levels of labour and capital. Crossover firms are also older, and more likely to have received support in the form of business or technical training. There also appear to be some differences in terms of finance-crossovers are more likely to belong to a savings and credit co-operative organization (SACCO) and to have received business development services such as assistance on business planning, developing promotional materials, and expanding market access. In terms of business practices, crossovers are significantly less likely to be running a business that they themselves started. In terms of personal characteristics, crossovers show some differences from non-crossovers: they are older, have a somewhat different education profile, and are more likely to be widowed.

Table 4 looks within the male-dominated sectors, and provides summary statistics to compare the male and female crossover entrepreneurs who operate there.

In terms of core business indicators, profit, revenue, and capital are not statistically significantly different across male- and female-owned firms in the crossover sectors. There is a significant difference in the number of workers, with female-owned firms averaging 1.7 fewer workers than their male-owned counterparts. This could be related to different allocation of capital and labour, but could also just be due to different sub-sector composition. When we turn to business practices, however, a number of significant differences emerge. Women, not surprisingly, are much more likely to mix household and financial resources than men, but are significantly less likely to have a business partner (indeed none of the crossovers does) and less likely to be registered. There appears to be some difference in finance-female entrepreneurs in these sectors are more likely to belong to a SACCO. The characteristics of the entrepreneurs are also different-women are older than their male counterparts, have a slightly different educational profile (although the years of education, not shown here, are not significantly different), are less likely to be married and more likely to be widowed, and score lower on our measure of technical skills. ${ }^{13}$

\footnotetext{
${ }^{13}$ This is a set of questions designed to carefully measure skills within a given sector (e.g. 'how far in inches from the scalp would you apply a chemical relaxer?' for hair salon or 'what is the minimum size of wire used for making an industrial welding machine?' for electrical).
} 
Table 4: Summary statistics for female-male comparison within crossovers' sectors-Kassida data set

\begin{tabular}{|c|c|c|c|c|c|}
\hline & Total & StDev & Crossover & Male & Difference \\
\hline \multicolumn{6}{|l|}{ Financials } \\
\hline Revenues past month (UGX '000) & 3,343 & 5,543 & 2,697 & 3,397 & -700 \\
\hline Profits past month (UGX '000) & 513 & 676 & 494 & 515 & -21 \\
\hline \multicolumn{6}{|l|}{ Investment } \\
\hline Net capital invested (UGX '000) & 3,865 & 7,749 & 5,312 & 3,744 & 1,569 \\
\hline Number of workers & 5.5 & 4.0 & 3.9 & 5.6 & $-1.7^{\star \star}$ \\
\hline Inputs consumed past month (UGX '000) & 1,659 & 4,169 & 968 & 1,717 & -749 \\
\hline \multicolumn{6}{|l|}{ Personal characteristics } \\
\hline Age & 39 & 10 & 42 & 39 & $4^{*}$ \\
\hline Married & 86 & 35 & 40 & 90 & $-50 * \star \star$ \\
\hline Widow & 3 & 16 & 32 & 0 & $32^{\star \star \star}$ \\
\hline Less than primary education & 9 & 28 & 30 & 7 & $24^{\star \star *}$ \\
\hline Primary school is max. education & 45 & 50 & 26 & 47 & $-20 *$ \\
\hline Secondary school is max. education & 29 & 46 & 30 & 29 & 1 \\
\hline Completed more than secondary & 17 & 38 & 13 & 17 & -4 \\
\hline Previously worker in sector & 17 & 37 & 12 & 17 & -5 \\
\hline Received business or technical training in past & 67 & 47 & 72 & 66 & 6 \\
\hline Financial literacy index (0-1) & 0.5 & 0.1 & 0.5 & 0.5 & 0.0 \\
\hline Technical literacy index (0-1) & 0.5 & 0.2 & 0.4 & 0.5 & $-0.1^{\star \star}$ \\
\hline Owns more than one business & 24 & 43 & 24 & 24 & 0 \\
\hline Household and business activities simultaneously & 12 & 33 & 44 & 9 & $35^{\star \star \star}$ \\
\hline \multicolumn{6}{|l|}{ Business characteristics } \\
\hline Business owner started this firm & 87 & 34 & 84 & 87 & -3 \\
\hline Saw market opportunity when starting business & 65 & 48 & 48 & 66 & $-18^{\star}$ \\
\hline Has business partners & 13 & 33 & 0 & 14 & $-14^{\star *}$ \\
\hline Business is registered & 64 & 48 & 44 & 66 & $-22^{\star \star}$ \\
\hline Age of business & 15 & 9 & 14 & 15 & -2 \\
\hline Size of business network (log) & 4 & 1 & 3 & 4 & -0.2 \\
\hline \multicolumn{6}{|l|}{ Access to finance } \\
\hline Has bank account & 63 & 48 & 60 & 63 & -3 \\
\hline Has received business support & 18 & 20 & 19 & 17 & 2 \\
\hline Belongs to SACCO & 9 & 28 & 32 & 7 & $25^{\star \star \star}$ \\
\hline Has received loan & 31 & 46 & 44 & 30 & 14 \\
\hline \multicolumn{6}{|l|}{ Harassment (past 12 months) } \\
\hline Has been sexually harassed & 7 & 25 & 8 & 7 & 1 \\
\hline Other type of harassment ${ }^{+}$ & 48 & 50 & 40 & 49 & -9 \\
\hline $\mathrm{N}$ & 324 & & 25 & 299 & \\
\hline
\end{tabular}

Notes: ${ }^{\star * *} p<0.01,{ }^{* \star} p<0.05,{ }^{*} p<0.1$. At the time of the survey, 1 US $\$=U G \times 2,250$. 
+ other type of harassment includes: threats to shut down business; shouting, scolding, making a nuisance in or near enterprise premises; vandalism of premises or merchandise; confiscation of property or merchandise; pushing or shoving; and beating.

Source: Authors' own construction.

The preceding discussion suggests that women crossovers and non-crossovers operate at different scales but also have a range of different business practices and personal attributes. In order to disentangle the relative impact of scale, we turn to production function estimates. We use a CobbDouglas production function of the form $Y_{i j}=A K_{i j}^{\alpha} L_{i j}^{\beta} M_{i j}^{\gamma}$ where $Y_{i j}$ is output of firm $i$ in sector $j$ and modelled as a function of capital, $K_{i j}$, labour, $L_{i j}$, intermediate material inputs, $M_{i j}$, and total factor productivity (TFP), $A$. This approach investigates if these factors account for the potential gaps in productivity between crossovers and other groups. Moreover, we assess if the observed differences are associated with suboptimal scale of operations for a specific group.

We acknowledge limitations of this analytical approach, namely the potential problems of endogeneity, including omitted variable bias, simultaneity, and self-selection issues. Nevertheless, such an analysis is helpful in identifying the initial factors that might be relevant in explaining the unconditional differences in performance.

Table 5 shows the estimates of production functions for female-owned firms, with and without controls for capital, labour, and material inputs.

Table 5: Production function estimates for female-owned enterprises

\begin{tabular}{|c|c|c|c|c|}
\hline \multicolumn{5}{|c|}{ Dependent variable: log Sales, restricted sample of women-only (KASSIDA data set) } \\
\hline & est1 & & est2 & \\
\hline & $\mathrm{B}$ & se & B & Se \\
\hline Crossover & $1.027^{\star \star \star}$ & 0.193 & $2.817^{\star}$ & 1.552 \\
\hline log Capital & & & $0.086^{\star \star}$ & 0.038 \\
\hline log Labour & & & $0.558^{\star \star \star}$ & 0.073 \\
\hline Log Material Inputs & & & $0.103^{\star \star \star}$ & 0.035 \\
\hline cross*InK & & & -0.121 & 0.140 \\
\hline cross*InL & & & 0.481 & 0.329 \\
\hline cross*InM & & & -0.091 & 0.159 \\
\hline _cons & $13.089^{\star \star \star}$ & 0.072 & $10.388^{\star \star \star}$ & 0.559 \\
\hline $\mathrm{N}$ & 309 & & 309 & \\
\hline r2 & 0.065 & & 0.256 & \\
\hline Non-crossovers CRS ( $p$-value of F-test) & & & $0.0014^{\star \star \star}$ & \\
\hline Crossovers CRS ( $p$-value of F-test) & & & 0.9519 & \\
\hline Crossovers RS $=$ Non-crossovers RS ( $p$-value of F-test) & & & 0.3266 & \\
\hline
\end{tabular}

Notes: ${ }^{\star \star \star} p<0.01,{ }^{\star \star} p<0.05,{ }^{*} p<0.1$. CRS $=$ constant returns to scale; RS = returns to scale.

Source: Authors' own construction. 
The first conclusion that can be drawn from this table is that crossovers have higher sales than non-crossovers, even after accounting for the capital, labour, and material inputs invested in the business, as the crossover variable remains significant in the second set of estimates. A second conclusion is that scale does not appear to be driving the enterprise outcome differences (here measured in terms of sales) between crossover and non-crossover female entrepreneurs. The coefficients on $\log$ capital, labour, and inputs are significant and smaller than 1, indicating decreasing returns to scale. The interaction terms with being a crossover firm (the last three rows) are not significant, indicating that they too experience decreasing returns to scale. Thus, differences in economies of scale do not appear to be driving the levels of sales across these two types of enterprises. Given that economies of scale are not driving the differences in revenues (and profits) between crossovers and non-crossovers, in the next section we turn to a range of other potential factors.

\section{$4 \quad$ Who crosses over?}

The women who break into male-dominated industries are different from women in traditional sectors, but there is no clear theory to explain why they do what they do. The literature has focused most on the choice of sector as a driving factor of gender-correlated profit and productivity differentials, and on the general constraints on female entrepreneurial activity-regardless of sector. But little to no attention has been given to the factors associated with women who successfully cross over. ${ }^{14}$

In order to examine this, in this section we examine three potential sets of explanations as to how a small subset of women end up with businesses in male-dominated industries. First, it could be that the women who cross over are 'superwomen' with superior skills and abilities. That is, they are above-average entrepreneurs, whose inherent intelligence and personality characteristics predispose them to success, and they can thus spot, and capitalize on, the opportunities presented by male-dominated sectors. Second, it could be that these women are entrepreneurs of average ability, but that their psychosocial development has helped them to circumvent or overcome the norms that identify certain professions as 'male' professions. Here we will look at a range of psychosocial characteristics including family background and role models, and an in-depth analysis of the entrepreneur's own account of how she ended up in her current profession. As indicated above, by psychosocial characteristics we mean the interrelation between social and individual factors expressed in someone's behaviours and mind. Third, it could be that these are the few women who somehow managed to overcome structural inequalities in education or human capital more generally, and access to finance, and thus move into these higher-return sectors.

The fact that these explanations are potentially overlapping was clearly evident in the qualitative work. One non-crossover woman captured the role of both norms and ability when she said: 'Such women are "superwomen". They have the characteristics of men.' On the other hand, a crossover foundry owner provides some insight into the importance of information and psychosocial development when she says: 'No, we are not different. It just takes a mindset and the necessary information to do this business.'

\footnotetext{
14 Among some of the studies that have looked at this issue, Bruni et al. (2004) and Anna et al. (2000) focus on women's choices for traditional female sectors, suggesting that these choices are driven by an assessment of which industry presents the lowest barriers to entry_-from capital to skills, but not on the specific factors that drive women into non-traditional sectors.
} 
For this analysis, we use the mixed-methods data set, which has a larger sample of crossovers and was designed fully for the purpose of this study. Hence, the depth of the information collected is much greater on this topic than the KASSIDA data set, which was originally designed to achieve other objectives.

\subsection{Information}

Before we take an in-depth look at the groups of factors, there is one potential market failure that could explain why some women do not cross over: information.

As shown in Figure 1, women who cross over have significantly higher profits than those who do not. It is possible that women who remain in female-dominated sectors simply do not know that they are making less. In our mixed-methods interviews, we asked about this. ${ }^{15}$

A tabulation of the answers shows that most of the women who do not cross over believe that they make the same as or more than those in the crossover sectors. ${ }^{16}$ As Figure 1 shows, some of them are right and some are wrong-the distributions of profits across crossover and noncrossover sectors overlap. Hence, in order to examine the potential information barrier, we divide the non-crossovers into those whose profits are below the mean in the crossover sectors and those whose profits are above the mean. Figure 3 shows the results.

The difference in the size of the bars confirms that the majority of the non-crossovers have lower profits than the mean for crossovers. Moreover, this figure shows that non-crossovers are unaware of the potential profitability of crossing over. Looking at the bar on the left for non-crossovers with lower profits than the mean for crossovers, almost 80 per cent of non-crossovers that make less than crossovers think they make the same or more.

\footnotetext{
${ }^{15}$ The questions used in the survey were the following: '[f crossover] Do you think you are making more, the same, or less money than you would if you were in a sector where women typically operate?'; '[If non-crossover] Do you think you are making more, the same, or less money than you would if you were in a sector where men typically operate?'. In both cases, the respondent had three options: 1-Making more money; 2-Making the same money; and 3-Making less money.

${ }^{16}$ It is also true that most of the crossovers think that they make more than the non-crossovers, even those crossovers that make less. However, this is only a major issue for non-crossovers, as they are the ones in general not taking advantage of the opportunities in the male-dominated sectors.
} 


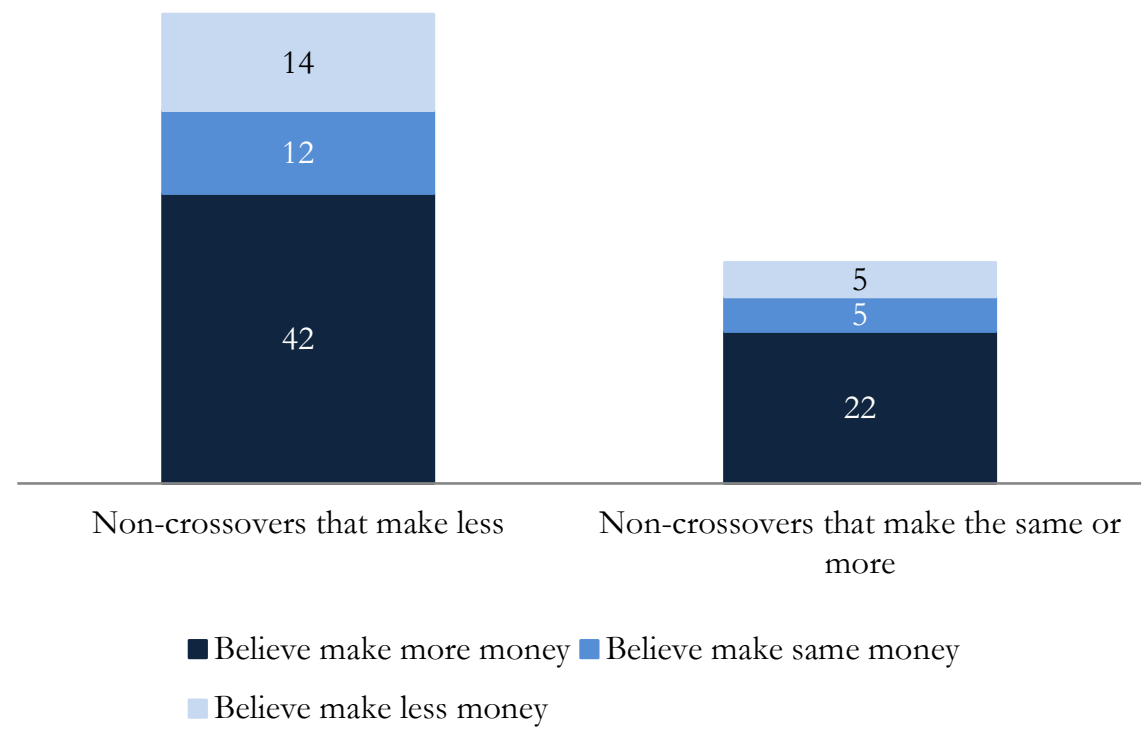

Source: Authors' own construction.

\subsection{Other factors}

While information is clearly one barrier to crossing over for some women, we now take a deeper look at the characteristics of the entrepreneurs themselves for other explanations. In order to examine these characteristics, we run a series of regressions using the mixed-methods data set. The results are in Table 6 . In what follows we discuss two sets of OLS regression results. ${ }^{17}$ Recall that the mixed-methods data set has two sets of non-crossover women: those who were matched to the crossovers on a small set of pre-business characteristics, and a group of randomly selected women. Given these two groups, we discuss results for both of them combined (columns A-C) and for the matched sample (columns D-F). Summary statistics for the variables used in the regressions can be found in Appendix Table A1.

\subsection{Skills and abilities}

We first analyse how innate skills and abilities are correlated with the decision to cross over to male-dominated sectors.

We used two cognitive tests, a digit-span recall exercise (measuring working memory) and a Raven's test (which captures fluid intelligence-the ability to understand complex problems and problem solving - as per Yuan et al. 2006) to determine if innate ability and/or intelligence predict the likelihood of being a crossover. A digit-span exercise involves respondents being shown a card with a four-digit number on it, with the card then being taken away. Ten seconds later, respondents are asked to repeat the number that was written on the card. If respondents recall the number

\footnotetext{
${ }^{17}$ We have also run probit models, obtaining similar results, although the results in these models are more extreme given the small sample size and the rare outcome. These are available from the authors upon request.
} 
correctly, enumerators then show them a five-digit number, with the process continuing up to 11 digits. In the Raven's progressive non-verbal reasoning test, enumerators provide 12 printed pages to each respondent, each of which contain a four-by-four pattern with one quadrant missing. Below the pattern are six figures, one of which fits the pattern, with the patterns becoming progressively more difficult. Respondents were given five minutes to complete as many of the patterns as possible. 
Table 6: Correlates of 'Being a crossover'

OLS combined

A

$\mathrm{B}$

$\begin{array}{ll}-0.003 & -0.001 \\ -0.113 & -0.093 \\ -0.224^{\star *} & -0.165^{\star *} \\ 0.030 & 0.047 \\ -0.037 & -0.038\end{array}$

Boy ratio, father owned enterprise interaction

$-0.037$
Marital status: reference-married/living with a partner

Divorced

Widowed

Never married

Religion: reference-Catholic

Protestant

Muslim

Pentacostal

\section{Region of birth: reference-Kampala}

Eastern

Central

Western

Northern

Foreign country

\section{Skills and abilities}

Raven's test score

Digit test score

Locus of control aggregate score

Agreeability score

Emotional stability score

Conscientious

Self-efficacy

\section{Psychosocial factors}

Male role model

First job was in non-male dominated sector

Exposure origination: Reference-self idea

Someone's suggestion

Was offered job in sector by family or friend

Observed others in sector

Worked for a wage in sector-qualitative recode

Exposure enabling factor: Reference-self idea

Suggested to me

$-0.128$

$-0.140$

$0.253^{\star}$

$-0.162$

$-0.088$

$-0.060$

0.030

0.009

0.531

$0.984^{*}$
$-0.176$

$-0.138$

$-0.086$

$-0.163$

$-0.198^{*}$

$-0.117$

0.196

$-0.112$

$-0.208$

$-0.215^{\star}$

$-0.193$

$0.291^{\star *}$

$0.453^{\star *}$

$0.451^{\star \star}$

$0.382^{\star}$

$-0.188^{*}$

$-0.158$

$-0.131$

$-0.221$

$-0.083$

$-0.077$

$-0.074$

$-0.078$

$-0.069$

$-0.024$

$-0.099$

$-0.029$

$-0.014$

$-0.085$

0.071

$\begin{array}{llllll}0.04 & 0.063 & 0.068 & 0.024 & 0.095 & 0.061 \\ -0.004 & 0.051 & -0.013 & 0.011 & 0.076 & 0.026 \\ 0.009 & 0.064 & 0.051 & 0.062 & 0.087 & 0.118 \\ 0.152 & 0.248 & 0.302 & 0.019 & 0.187 & 0.180\end{array}$

$\begin{array}{lll}-0.092 & -0.024 & -0.106\end{array}$

$-0.034^{\star \star}$

$-0.032^{* *}$

$-0.034^{\star \star}$

$-0.035^{\star \star}$

$-0.033^{* *}$

$-0.028^{\star}$

0.039

0.052

0.037

0.026

0.046

$-0.069$

$-0.250$

$-0.130$

$-0.143$

$-0.598$

$-0.129-0.050$

$-0.118$

$-0.274$

$-0.106$

$-0.450$

$-1.371^{\star \star}-0.976^{\star \star}$

$-1.384^{\star *}$

$-0.77$

$-0.471$

$-0.797^{\star}$

0.268

0.622

0.32

0.555

$-0.325$

1.106*

0.898

0.333

0.548

0.533

\begin{tabular}{|c|c|c|c|c|c|}
\hline $0.220^{\star \star}$ & $0.214^{\star \star}$ & $0.188^{*}$ & $0.204^{\star}$ & 0.124 & 0.167 \\
\hline$-0.461^{\star \star \star}$ & $-0.434^{\star \star \star}$ & $-0.398^{\star \star \star}$ & -0.619 *** & $-0.644^{\star \star \star}$ & $-0.532^{\star * \star}$ \\
\hline & $0.216^{\star \star}$ & & & $0.232^{\star}$ & \\
\hline & $0.315^{\star \star}$ & & & 0.21 & \\
\hline & 0.149 & & & 0.104 & \\
\hline & 0.028 & & & -0.025 & \\
\hline
\end{tabular}

$0.334^{*}$

0.241 


\begin{tabular}{|c|c|c|c|c|c|c|}
\hline \multicolumn{3}{|l|}{ Offered job by a family member or friend } & \multicolumn{3}{|l|}{0.175} & 0.158 \\
\hline \multicolumn{3}{|l|}{ Observed others } & \multicolumn{3}{|l|}{0.104} & 0.118 \\
\hline \multicolumn{3}{|l|}{ Worked for stranger } & \multicolumn{3}{|l|}{-0.158} & -0.169 \\
\hline \multicolumn{3}{|l|}{ Was trained } & \multicolumn{3}{|l|}{0.057} & 0.115 \\
\hline \multicolumn{7}{|l|}{ 4. Capital } \\
\hline Years of education & -0.005 & 0.008 & -0.008 & -0.012 & 0.039 & -0.022 \\
\hline Years of education squared & 0.000 & -0.001 & 0.000 & 0.000 & -0.004 & 0.001 \\
\hline Owned an enterprise in another sector & $0.151^{*}$ & $0.148^{\star}$ & $0.141^{*}$ & $0.193^{\star *}$ & $0.173^{*}$ & $0.175^{\star}$ \\
\hline Choose sector for low capital requirements & 0.050 & 0.019 & 0.005 & 0.118 & 0.054 & 0.032 \\
\hline Delayed starting enterprise saving for capital & $0.148^{*}$ & 0.123 & 0.136 & 0.107 & 0.142 & 0.051 \\
\hline Years of experience in previous jobs & -0.009 & -0.011 & -0.009 & -0.002 & 0.001 & -0.002 \\
\hline Previous years of experience squared & 0.000 & 0.000 & 0.000 & 0.000 & 0.000 & 0.000 \\
\hline Trained while waiting to start business & & 0.017 & & & 0.180 & \\
\hline Constant & 1.033 & 0.520 & 1.004 & $1.689^{\star *}$ & 0.660 & $2.176^{\star \star}$ \\
\hline N & 133 & 133 & 133 & 91 & 91 & 91 \\
\hline Adjusted R-Squared & 0.370 & 0.407 & 0.432 & 0.566 & 0.588 & 0.592 \\
\hline
\end{tabular}

Notes: * $p<0.1,{ }^{* \star} p<0.05,{ }^{* * *} p<0.001$.

Source: Authors' own construction.

In Table 6, we can see that the digit-span test is not a significant predictor of crossing over. On the other hand, the results on the Raven's test suggest that women with less fluid intelligence are more likely to cross over. While statistically significant, these effects are fairly small: getting one more matrix correct is associated with about a 3-percentage-point decrease in the likelihood of crossing over.

In addition to cognitive measures, the team considered a variety of non-cognitive tests to gauge respondents' levels of innate entrepreneurial spirit (see Khwaja and Klinger, ongoing, and Rauch and Frese 2007). This class of measures may be useful in predicting the success of entrepreneurs over time (see, for example, de Mel et al. 2010). We asked respondents to rate a level of agreement with questions that evaluated their personal levels of self-efficacy, locus of control, agreeableness, conscientiousness, and emotional stability on a scale from strong disagreement to strong agreement. As with the cognitive measures, the results in Table 6 do not show that the crossovers score unambiguously as more entrepreneurial than non-crossovers. Three of our measures (locus of control, agreeableness, and conscientiousness) show no correlation with the likelihood of being a crossover. However, women who score lower on emotional stability (this includes getting irritated more often and stressed about things) are more likely to be crossovers. On the other hand, women who score higher on self-efficacy (the ability to complete tasks and reach goals) are significantly (at the 10 per cent level) more likely to be crossovers in a subset of these specifications.

In a meta-analysis of a wide range of studies on the relationship between personality traits and business creation and success, Rauch and Frese (2007) find that self-efficacy is positively correlated with business success, but not with business creation. This would suggest that the crossovers have personality traits in common with successful entrepreneurs. On the other hand, Rauch and Frese also find that locus of control is significantly related to success, while Zhao and Seibert (2006) find differences between entrepreneurs and managers on agreeableness. And the lack of a significant 
difference on these dimensions suggests that the crossovers are not markedly different to the noncrossovers in key non-cognitive entrepreneurship traits.

In sum, these results, combined with the cognitive tests, show that while the women who cross over may be different in some dimensions of personality, they are not more likely to score uniformly higher in skills that would aid them in becoming successful entrepreneurs.

\subsection{Psychosocial factors}

Individual characteristics interact with one's environment in a range of ways that might impact the choice to cross over into male-dominated sectors. In order to make this wide group tractable, we break this set of factors down into different sub-groups.

We start with an examination of the family background of these entrepreneurs. As shown in Table 6, women whose mothers are entrepreneurs are less likely to cross over, suggesting a continuation of professions within the family. Nonetheless, while we might expect the father's entrepreneurial background or the sex composition of one's siblings to matter as an influence in crossing over to 'male' activities, the results in Table 6 indicate that they do not.

As the summary statistics discussed above indicate, women who cross over are less likely to have started their own business and are more likely to be widowed. This would suggest that a central path to crossing over is to inherit a business, perhaps from a husband. However, our analysis in Table 6 indicates that when we control for a range of factors, this does not appear to be a central pathway to becoming a crossover. Relative to married women, divorced and widowed women are, if anything, less likely to be crossovers. Women who have never been married or have never lived with someone are significantly more likely than married women to be crossovers.

A critical path to crossing over seems to be having had a male role model in youth. In seeking to understand the importance of different psychosocial factors, we identify the women's reported role model in youth. Table 6 shows that women with a male role model are 12-22 percentage points more likely to be crossovers. This provides an indication of how men are involved in the transition of women to higher-profit sectors. We asked the respondents who these role models were, and the results are presented in Table 7. 
Table 7: Identity of role model in youth (\%)

\begin{tabular}{llll} 
& Crossover & Non-crossover & Difference \\
Male & 32.6 & 18.1 & $14.5^{\star}$ \\
Female & 67.4 & 81.9 & $-14.5^{\star}$ \\
& 100 & 100 & \\
Male relative & 21.3 & 14.0 & 7.3 \\
Female relative & 40.4 & 55.8 & $-15.4^{\star}$ \\
Non-related male & 10.6 & 5.8 & 4.8 \\
Non-related female & 27.7 & 24.4 & 3.2 \\
& 100 & 100 & \\
$\mathrm{~N}$ & 47 & 86 & 133 \\
\hline
\end{tabular}

Notes: ${ }^{\star * \star} p<0.01,{ }^{* \star} p<0.05,{ }^{*} p<0.1$.

Source: Authors' own construction.

Within the male relative category, fathers are a more common role model for crossovers relative to non-crossovers. However, as shown in the results on family background in Table 6 , the channels of influence are not as direct as assuming that crossovers became entrepreneurs in a sector because it was where their fathers used to work, since there is no significant relationship with the variable 'Father owned enterprise'. ${ }^{18}$

The importance of certain kinds of men is again evident when we ask who first exposed the entrepreneurs to their sector. Table 8 shows the distribution of the responses of crossovers versus non-crossovers.

\footnotetext{
${ }^{18}$ We tested for, and did not find, collinearity between 'Father owned enterprise' and 'Male role model'.
} 
Table 8: Identity of individuals introducing entrepreneurs to their sectors (\%)

\begin{tabular}{llll}
\hline & Crossover & Non-crossover & Difference \\
Mother & 1.8 & 10.6 & $-8.8^{\star \star}$ \\
Father & 7.3 & 1.9 & $5.4^{\star}$ \\
Other male family member & 20.0 & 5.8 & $14.2^{\star \star \star}$ \\
Other female family member & 10.9 & 16.4 & -5.4 \\
Female friend/community member & 29.1 & 26.0 & 3.1 \\
Male friend/community member & 12.7 & 3.9 & $8.9^{\star *}$ \\
Teacher & 1.8 & 26.9 & $-25.1^{\star \star *}$ \\
Other & 16.4 & 8.7 & $7.7^{\star *}$ \\
$\mathrm{~N}$ & 55 & 104 & 159 \\
\hline
\end{tabular}

Notes: ${ }^{* \star} p<0.01,{ }^{\star *} p<0.05,{ }^{*} p<0.1$.

Source: Authors' own construction.

Table 8 shows that crossovers are more likely to be introduced to their sector relative to noncrossovers by fathers, male friends/community members, and other male family members. Two of our respondents summarize the role of these male mentors: 'Through his encouragements [and] help, I kept my savings until I got what was enough to start up. He mentored me after I finished my diploma.'; 'My spouse was in carpentry when we married. His friend taught me the skill because my spouse wanted me only to manage and do sales for him.'

On the other hand, non-crossovers are more likely to be introduced to their sectors by mothers and teachers. Indeed, teachers are one of the main sources of exposure to the non-crossover sectors, particularly in the case of tailors who learn how to sew at school or attend special training provided by other institutions (church, charities, and non-governmental organizations). This suggests that the education system, as it now stands, is one of the reinforcing factors in maintaining the gender segregation of sectoral choice.

Returning to Table 6, we also look at variables which may be critical in terms of initial exposure. Specifically, having a first job in a non-male-dominated sector is negatively associated with being a crossover. This suggests strong path dependence in these women's career-with an initial job in a non-crossover sector, they are much less likely to switch. ${ }^{19}$

In an effort to better understand the pathways to becoming a crossover, we also undertook a coding exercise of women's stories of how they ended up in their current sector of employment, drawing on both quantitative and qualitative data. Two of the authors coded the answers separately and then compared and reconciled their answers. ${ }^{20}$ In particular, we coded two separate sets of variables from these data. The first is what we label the exposure origination, which is meant to capture where the original idea/impetus for choosing a sector came from. As individuals cited many factors in explaining their story in the decision to start/join a business in a specific industry, we ordered these factors through time. The first identified factor was coded as the exposure origination and is used under the assumption that what matters is where the original idea comes

\footnotetext{
${ }^{19}$ While we use the term crossover, very few women cross over from female-dominated sectors to male-dominated ones once they have started working. This is typically their first business activity.

${ }^{20}$ Disagreements were few.
} 
from. As per Table 6, the options for coding of the exposure to sector include self-idea, someone's suggestion, offered job in sector by family or friend, observed others, or worked for a wage in the sector.

Alternatively, we use the last identified factor to define the sector participation enabling factor, which would imply that the last step is explanatory of the final decision taken. For example, one of the crossovers in metal fabrication who described her process of getting into the business as follows: 'I lost my capital in charcoal selling and I was unemployed, then a friend invited me to join a workshop of metal fabrication where I was taught the skills. She first taught me how to produce, and then I started my own business.' Her origination factor is 'someone suggested' while her enabling factor is 'training'. Both the sector participation origination and the sector participation enabling factor are included in the analysis in Table 6. However, since they are obviously overlapping, we run them separately in columns B and C and $\mathrm{E}$ and $\mathrm{F}$.

When we focus on what started the process, we can see that, relative to the idea coming from the entrepreneur herself, the role of others appears to be significantly more important. Someone's suggestion and being offered a job in the sector by a friend or family member are significant and positive in predicting the likelihood of crossing over, relative to own idea. These results seem to confirm the importance of active engagement from others in enabling women to move into maledominated sectors. Our participation enabling factors suggest that, relative to self-initiation, 'suggested to me' is positively correlated with being a crossover, but only in the combined sample, and significant only at the 10 per cent level.

The qualitative work confirms active exposure to the sector as a relevant intermediate step in the trajectory to becoming a crossover, either by engaging in actively learning the trade or through being taken to the firm by an active intermediary or enabler-friend, family member-who not only suggests starting in the trade but also brings the person to either their own business or someone else's.

\subsection{Capital}

We now focus on capital and skills that can be acquired in the market, which are factors typically associated with gender gaps in entrepreneurship. We start our examination of capital with human capital. As can be seen in section 4 in Table 6, education, the most common measure of human capital, does not significantly affect the probability that a woman is a crossover. This is also true for years of experience in the previous job, and age (section 1), which will capture all accumulated experience. One area where experience might matter is whether the entrepreneur owned an enterprise in another sector. This is positively correlated with being a crossover (at the 10 per cent level). On balance, human capital does not appear to affect the probability that a woman entered a male-dominated sector.

It is difficult to capture the importance of credit constraints at the time that a woman made a decision to enter these sectors. In order to get at the influence of financial capital, we asked two questions: (1) did the woman choose this sector because of the low capital requirements (which is likely to be negatively related to becoming a crossover given the higher capital intensity of the crossover sectors); and (2) did the entrepreneur choose to delay setting up her business, and was this because she was saving to accumulate capital? The results in Table 6 indicate that these entrepreneurs do not choose their sector-crossover or non-crossover-based on the capital requirements. The one exception to this is when we use the combined sample and do not control for the pathway to becoming a crossover. In this case, delaying the enterprise start-up to 
accumulate capital is positively correlated with being a crossover, but only at 10 per cent. We will discuss (current) sources of credit further in Section 5.

In sum, and as discussed in this section, most forms of human and financial capital do not appear to play a role in being a crossover. In terms of skills and abilities, crossover entrepreneurs do not seem to have more innate intelligence than non-crossovers. Their personalities are somewhat different, but not in ways that uniformly predict business success. What seem to be critically important for the crossover decision, however, are psychosocial factors. Key among these is the importance of male role models, and the active engagement of these role models in engaging the female entrepreneur in the activities of the crossover sector and in breaking traditional norms. These factors give us some insight into how female entrepreneurs become crossovers.

But the challenge is not only to successfully break into a new sector, but also to stay in the sector. In the next section, we examine some of the challenges crossovers face in sustaining their businesses. $^{21}$

\section{$5 \quad$ Sustaining a crossover business}

The issues crossover entrepreneurs face in developing their businesses start with the establishment of the enterprise. Table 9 shows the primary business-related challenges faced by crossovers and non-crossovers when establishing their enterprise.

\footnotetext{
${ }^{21}$ Section 5 draws (except where noted) exclusively on the mixed-methods data set.
} 
Table 9: Main problems faced by women when starting their business

\begin{tabular}{llll}
\hline & Crossover & Non-crossover & Difference \\
Finding staff willing to work for a woman & 1.6 & 0.8 & 0.8 \\
Finding right staff (woman not mentioned) & 6.3 & 6.7 & -0.3 \\
Low technical skills and experience & 20.6 & 0.8 & $19.8^{\star \star \star}$ \\
Finding right suppliers & 7.9 & 0.8 & $7.1^{\star \star \star}$ \\
Finding a location/premises & 11.1 & 15.8 & -4.7 \\
Accessing credit & 17.5 & 23.3 & -5.9 \\
Balancing home and work life & 1.6 & 0.8 & 0.8 \\
Distribution/delivery of products to clients & 3.2 & 0.0 & $3.2^{\star \star}$ \\
Finding customers willing to buy from a woman & 3.2 & 0.8 & 2.3 \\
Finding customers (woman not mentioned) & 4.8 & 42.5 & $-37.7^{\star \star *}$ \\
Infrastructure and utilities & 4.8 & 1.7 & 3.1 \\
Corruption and bribes & 1.6 & 0.0 & 1.6 \\
Sexual harassment & 0.0 & 0.8 & -0.8 \\
Other & 15.9 & 5.0 & $10.9^{\star \star * *}$ \\
N & 63 & 120 & 183
\end{tabular}

Notes: ${ }^{\star * \star} p<0.01,{ }^{* \star} p<0.05,{ }^{*} p<0.1$.

Source: Authors' own construction.

Some of the problems we might expect women who are pioneers in a sector to face are in evidence in Table 9. The most common constraint that crossovers mention is low technical skills. Here, the mixed-methods data lines up with our earlier discussion of the KASSIDA data-women's lower technical skills within these sectors persist. A smaller fraction of crossovers also cite issues of finding suppliers. When we ask them directly if their suppliers charge them more because of their gender, 13 per cent of crossovers say yes, compared to 4 per cent of non-crossovers.

Clients and suppliers acknowledge that female business owners have lower technical skills, which, for example, limits the range of products the crossovers can offer. According to these clients and suppliers, the crossovers 'depend too much on their male employees to carry out hard tasks such as firing, lifting, and delivering'. Furthermore, when asked 'If you had a big contract, who would you give it to: a male or female business owner?', the qualitative responses pointed to male-owned firms when it came to metal fabrication and carpentry because of the skill levels required to deliver on time. ${ }^{22}$

Finally, a small fraction of crossovers refer to problems with the distribution/delivery of products to clients, while no non-crossovers cite these issues-likely due to the nature of their business. But finding customers in the first place is not a challenge faced by the crossovers, while this is far and away the major problem cited by non-crossovers (over 44 per cent). From the focus group

\footnotetext{
${ }^{22}$ If this is the case, it would suggest crossovers would engage in a higher number of smaller activities than men. Information on type of products sold suggests this is the case for women doing metal work. One woman noted that her difficulties in finding male employees to help with the physically demanding work had influenced her decision in the type of products she was offering.
} 
discussions with clients of metal fabrication and carpentry, it emerges that crossovers are perceived as being better at tracking their orders and as providers of better customer care than male business owners.

Given that crossovers are defying gender norms, we might expect crossover entrepreneurs to be more isolated. When asked if they have difficulty establishing networks, 40 per cent of crossover entrepreneurs say yes compared to only 14 per cent of non-crossovers. However, in some dimensions, crossovers are able to overcome networking difficulties. They know roughly the same number of people in their sector as non-crossovers do, although fewer of these people (but not statistically significantly fewer) are women. Fifty-four per cent of them interact with other business owners at least once a month to discuss business issues, while this is true for only 39 per cent of non-crossovers. ${ }^{23}$ And crossovers are as likely as non-crossovers to interact with other women to discuss business issues.

As mentioned in the previous sections, self-efficacy plays a positive role in entering the sector, but also in sustaining the business. Seasoned women entrepreneurs see themselves as able to effectively master all crucial aspects of their trade, no doubt by applying life skills they have developed in their paths as independent businesswomen. This is also reflected in the qualitative work in the fact that, compared with women in traditional sectors, crossovers are less concerned about social perceptions of their actions and show lower fear of social shame.

Another potential dimension in which issues may arise for crossover entrepreneurs is in the harassment they receive as they operate their business. Table 10 compares reported sources of harassment for crossover and non-crossover female entrepreneurs. The major form of harassment that both crossovers and non-crossovers face is a threat to shut down the business (most commonly by the police), but this threat is significantly more frequent for crossovers. In addition, crossovers experience more frequent vandalism of their premises. Both of these could be because crossovers stand out within their sectors. However, they could also be features of the sectors within which crossovers operate. For example, compare a metal fabricator and a caterer. A caterer can pack up most of her capital and move her business quite easily, while a metal fabricator is more likely to have larger machinery that makes her business less mobile. ${ }^{24}$

\footnotetext{
${ }^{23}$ This difference is significant at 10 per cent.

${ }^{24}$ The KASSIDA data set (Table 4) provides some support for this fact, as there are no significant differences between men and women in the crossover sectors across the forms of harassment. However, this is not a primary focus in the KASSIDA data collection and some numbers appear less reliable (e.g. much lower rates of sexual harassment).
} 
Table 10: Harassment in the past 12 months (\%)

\begin{tabular}{llll}
\hline & Crossover & Non-crossover & Difference \\
Threats to shut down business & 33.9 & 20.0 & $13.9^{\star *}$ \\
$\begin{array}{l}\text { Shouting, scolding, making a nuisance in or near } \\
\text { enterprise premises }\end{array}$ & 21.0 & 15.0 & 6.0 \\
Vandalism of premises or merchandise & 8.1 & & $5.5^{\star}$ \\
Confiscation of property or merchandise & 8.1 & 2.5 & 1.3 \\
Pushing or shoving & 14.5 & 6.7 & 2.8 \\
Sexual proposals & 29.0 & 11.8 & $12.2^{*}$ \\
Fondling or inappropriate touching & 3.2 & 16.8 & 0.7 \\
Beating & 6.5 & 2.5 & 3.9 \\
Arson & 3.2 & 2.5 & 2.4 \\
Witchcraft & 19.4 & 0.8 & 4.8 \\
N & 62 & 14.5 & 181 \\
\hline
\end{tabular}

Notes: ${ }^{* \star} p<0.01,{ }^{\star *} p<0.05,{ }^{*} p<0.1$.

Source: Authors' own construction.

The third significant difference in harassment unambiguously indicates the vulnerability of women who choose to cross over- they are almost twice as likely to experience unwanted sexual proposals than those who do not cross over, ${ }^{25}$ although they are equally likely to report sexual harassment to be among the three most prominent problems faced by businesswomen in Uganda interested in entering their sector (23 per cent of crossovers and 21 per cent of non-crossovers ${ }^{26}$ ). Harassment also appears prominently as part of the disadvantages faced by crossovers as seen by clients and community leaders.

When we asked entrepreneurs about the issues they currently face in their business, the most common answer (at around 35 per cent) for both crossovers and non-crossovers was credit. Table 11 shows the sources of credit for these entrepreneurs in the last 12 months.

\footnotetext{
${ }^{25}$ These findings on sexual harassment are not confirmed in the KASSIDA data set, where reporting of sexual harassment is lower in general and in particular for crossovers. This is likely partly related to methodological differences (as Ellsberg et al. 2001). Ellsberg and Heise (2002) show when comparing differences in reported experiences of violence that these issues are very sensitive to methodological factors such as type and structure of the survey, interview setting and privacy levels, sex of the interviewer, and whether the instrument is quantitative or qualitative. The mixed-methods survey design and implementation-including a more personal approach to individuals' own experience in the form of a dialogue — was better suited to learning about these issues. United Nations (2014) and Ellsberg and Heise (2005) also note that under-reporting of violent experiences in questions related to violence inserted in surveys about other unrelated issues is of frequent occurrence.

${ }^{26}$ Table 9 only reports on the main problem.
} 
Table 11: Borrowing sources in the past 12 months

\begin{tabular}{llll}
\hline & Crossover & Non-crossover & Difference \\
Spouse/partner & 9.5 & 3.3 & $6.2^{*}$ \\
Female family member & 9.5 & 6.7 & 2.9 \\
Male family member & 7.9 & 5.8 & 2.1 \\
Female friend/community member & 6.3 & 15.8 & $-9.5^{\star}$ \\
Male friend/community member & 3.2 & 5.0 & -1.8 \\
Other business & 3.2 & 0.8 & 2.3 \\
Microfinance institution & 28.6 & 30.0 & $-1.4^{*}$ \\
Bank & 17.5 & 6.7 & $10.8^{* *}$ \\
$\mathrm{~N}$ & 63 & 120 & 183 \\
\hline
\end{tabular}

Notes: ${ }^{* \star} p<0.01,{ }^{\star *} p<0.05,{ }^{*} p<0.1$.

Source: Authors' own construction.

Not surprisingly, given the capital-intensive nature of their businesses, crossovers get credit from different sources. The most common source of credit in the last year for crossovers was a microfinance institution (29 per cent), followed by a formal bank-18 per cent of crossovers used this source, compared with only 7 per cent of non-crossovers. Crossovers are less likely than noncrossovers to have borrowed from a female friend/community member, perhaps because noncrossovers can rely on other women who work in their sectors. On the other hand, 10 per cent of crossovers borrowed from their spouse, compared to only 3 per cent of non-crossovers.

A large majority of entrepreneurs contribute to household expenses. When asked if their spouse knew about their business, 94 per cent of non-crossovers answered yes, compared to 78 per cent of crossovers. Reported spousal knowledge of earnings was much lower-34 per cent for crossovers and 21 per cent for non-crossovers (this difference is not statistically significant). Table 12 shows the intended uses of contribution for those that contribute to household expenses. One interesting and significant difference is that crossovers are more likely to contribute to covering the often large and lumpy expenditure on school fees. 
Table 12: Contribution of money from business to household expenditure

\begin{tabular}{llll}
\hline & Crossover & Non-crossover & Difference \\
Regular contribution of money to household & 88.7 & 93.2 & -4.5 \\
If contributes, on what? & & & -6.4 \\
Food for the family & 92.7 & 99.1 & $14.4^{\star \star}$ \\
School fees & 25.5 & 11.0 & 3.6 \\
Property payments/rent & 10.9 & 7.3 & -1.1 \\
Family transport costs & 23.6 & 24.8 & $-14.3^{*}$ \\
Cooking fuel & 61.8 & 76.1 & 1.8 \\
Give money to husband & 1.8 & 0.0 & 0.0 \\
Taking care of parents/elderly & 0.0 & 0.0 & 1.8 \\
Give money to extended family & 1.8 & 0.0 & $3.6^{\star *}$ \\
Other & 3.6 & 0.0 & 179 \\
$\mathrm{~N}$ & 62 & 117 & 0.0 \\
\hline
\end{tabular}

Notes: ${ }^{\star *} p<0.01,{ }^{* \star} p<0.05,{ }^{*} p<0.1$.

Source: Authors' own construction.

In addition to the monetary contributions, it is possible that the household demands on women's time may constrain women's ability to provide the supervision that larger crossover enterprises require. However, as the KASSIDA data discussed above indicate, crossover women manage to combine work and family duties more frequently than their male counterparts with no widespread adverse impacts on profits. Indeed, when we compare crossover women to non-crossover women using the mixed-methods data set, we find that crossover women actually spend significantly fewer hours per week (62 hours versus 67) working in the business. And they spend about the same amount of time taking care of children and/or the elderly (14 hours versus 16-not statistically different). This result is a bit surprising, since childcare duties are often cited as a constraint on female-owned enterprise profits. What these results show us is that if childcare duties are indeed a constraint, they matter through limits on the growth of the firm (e.g. as the entrepreneur has less hours to supply), but not through the sectoral choice.

\section{Designing policies to support women who want to cross over}

This paper explores an area heretofore unexplored in the literature on enterprises and occupational segregation. As such, there is not a literature on potential policies for us to draw on. In what follows, we provide a set of policy recommendations based on what is suggested by the analysis above. However, given the lack of tested interventions in this area and the limitations of descriptive analysis, experimentation and rigorous impact evaluations ${ }^{27}$ of these policies-using different combinations of interventions and in different contexts - are critical. It is also important to note that we limit our recommendations to the factors identified above that are malleable. Some, such

\footnotetext{
${ }^{27}$ Given that these policies will involve directly confronting well-entrenched norms, it is critical to integrate qualitative work in these rigorous impact evaluations.
} 
as the fact that crossovers are more likely to have a male role model in youth, are unlikely to be changed by a policy intervention.

The first ingredient in a policy to support women who wish to cross over is information. A significant majority of the women who have not entered male-dominated sectors think that they make the same as or more than enterprise owners in these sectors when, in fact, they do not. And they recognize that information is a factor and it needs to come early in life. ${ }^{28}$ The provision of information will enable these women, in the first instance, to make better-informed choices about their sector of operation. Findings from a 2011 evaluation of the Kenya national vocational training programme suggest that this approach may be enough to change minds (Hicks et al. 2011). In the Kenya programme, before training enrolment decisions and course selections, some women received information on the difference between expected earnings for graduates of maledominated trades versus female-dominated trades, as well as a video presentation about successful Kenyan female car mechanics. Women who received the intervention were 9 percentage points more likely to express preference for a male-dominated course, and 5 percentage points more likely to enrol in one.

However, as our research shows, information alone is not likely to be enough. A second element of a potential programme is to provide supportive engagement with those who can help guide the female entrepreneurs as they seek to enter and then operate businesses in male-dominated sectors. Ideally, this mentor will be drawn from the entrepreneur's existing network of family and friends, but it may work as well with sympathetic (or empathetic) outsiders. In our qualitative work, both crossovers and non-crossovers agreed that they would allow their daughters to cross over if someone reliable was to introduce them to the sector.

Third, while we do not find skills to be a binding constraint for women who cross over, our analysis suggests that it can be important to be exposed to the sector from early on, and one way to achieve this is to work or undertake apprenticeships, ideally in businesses owned by people within the networks of trust. The qualitative work makes a distinction between active and passive observation. Passive participation characterizes women in female-dominated sectors. Active participation, which is key for crossovers, consists of being close to the business, working in a business doing sales or managing the storefront, providing services and inputs for crossover business, and/or being invited to learn. Apprenticeships or other experiences working in a crossover business may be a critical way not only to impart basic skills to potential crossovers but also to receive this active participation.

In addition to these elements, a number of other considerations may help with the success of this type of intervention. First, the timing of different actions is important. Crossovers report requiring a longer time to start their businesses primarily because apprenticeship and learning the trade takes time. Combined with the fact that crossovers are much more likely to have their first job in a crossover sector, our results suggest the importance of aiming to support women without much experience working in a traditional female sector. This would imply targeting younger women who are just entering the labour market. ${ }^{29}$

Second, if these interventions are to be tested on any substantial scale, it is important that policy engages the local power structure, given the potential disruption to long-standing norms.

\footnotetext{
28 'No, they [crossovers] are not different, any woman can do that kind of work, provided she is exposed early enough', observed a hair salon owner.

${ }^{29}$ Another option would be older women without experience in female-dominated sectors, but in most countries this is a very small proportion of the population.
} 
Responses from our key informant interviews show both the potential opposition, but also the potential for support among leaders. One Muslim leader from Lufula Zone stated: 'I would not recommend anyone to sensitize to our women about male-dominated sectors. It is "Haramuh"not accepted by religion. The way they dress is not allowed because they put on tight trousers. They cannot pray five times a day, they have no time.' On the other hand, a male Local Chairman in Musoke Zone said: 'It is a very good idea. I also wanted my daughters to join such jobs because these jobs pay well ... [Crossing over] is a very good thing and that is where the world is heading. If there was an opportunity, I would join the team to sensitize the people in my zone.' Religious and cultural restrictions, social sanctions, and the fear of being seen as 'incomplete women-not well groomed or tidy, in activities that require [one] to "act like a man", and likely to fail to get married and have children', can raise obstacles to crossing over. And indeed, the fact that selfefficacy is correlated with the probability that an entrepreneur is a crossover is in line with the idea that these norms are a binding constraint. These social perceptions will not only impact sector choice, but might also prevent women from accessing credit or financial support or building lasting networks. Engaging the right local political and religious leaders may provide powerful support to women in defying these norms and moving to more profitable sectors.

Finally, once women start to cross over, it is critical to support them as their businesses grow (e.g. with support for networks or crossover-specific business organizations). As the data and the words of our respondents indicate, the process of crossing over is a continuous one, with different issues arising at different stages in the process. 


\section{References}

Anna, A.L., G.N. Chandler, E. Jansen, and N.P. Mero (2000). 'Women Business Owners in Traditional and Non-Traditional Industries'. Journal of Business Venturing, 15(3): 279-303.

Aterido, R., and M. Hallward-Dreimeier (2011). 'Whose Business Is It Anyway? Closing the Gender Gap in Entrepreneurship in Sub-Saharan Africa'. Small Business Economics, 37(3): 44364.

Bardasi, E., and A. Getahun (2008). 'Unlocking the Power of Women'. Chapter prepared for the Ethiopia Investment Climate Assessment (ICA). In World Bank, Toward the Competitive Frontier: Strategies for Improving Ethiopia's Investment Climate. Washington, DC: World Bank.

Bardasi, E., S. Sabarwal, and K. Terrell (2011). 'How Do Female Entrepreneurs Perform? Evidence from Three Developing Regions'. Small Business Economics, 37: 417-41.

Bruhn, M. (2009). 'Female-Owned Firms in Latin America: Characteristics, Performance, and Obstacles to Growth'. Policy Research Working Paper 5122. Washington, DC: World Bank.

Bruni, A., S. Gherardi, and B. Poggio (2004). 'Entrepreneur-Mentality, Gender and the Study of Women Entrepreneurs'. Journal of Organizational Change Management, 17(3): 256-68.

Brush, C.G. (1992). 'Research on Women Business Owners. Past Trends: A New Perspective and Future Directions'. Entrepreneurship, Theory \& Practice, Summer: 5-30.

Rijkers, B., and R. Costa (2012). 'Gender and Rural Non-Farm Entrepreneurship'. World Development, 40(12): 2411-26.

de Mel, S., D. McKenzie, and C. Woodruff (2009). 'Are Women More Credit Constrained? Experimental Evidence on Gender and Microenterprise Returns'. American Economic Journal: Applied Economics, 1(3): 1-32.

de Mel, S., D. McKenzie, and C. Woodruff (2010). 'Who Are the Microenterprise Owners? Evidence from Sri Lanka on Tokman versus De Soto'. In J. Lerner and A. Schoar (eds), International Differences in Entrepreneurship. Chicago: University of Chicago Press for the NBER.

Dolado, J., F. Felgueroso, and J. Jimeno (2003). 'Discrimination et inégalités/Discrimination and Unequal Outcome'. Annals of Economics and Statistics/Annales d'Économie et de Statistique, 71/72: 293-315.

Ellsberg, M., and L. Heise (2002). 'Bearing Witness: Ethics in Domestic Violence Research'. The Lancet, 359(9317): 1599-604.

Ellsberg, M., and L. Heise (2005). 'Researching Violence against Women. A Practical Guide for Researchers and Activists'. Washington, DC: World Health Organization.

Ellsberg, M., L. Heise, R. Pena, S. Agurto, and A. Winkvist (2001). 'Researching Domestic Violence against Women: Methodological and Ethical Considerations'. Studies in Family Planning, 32(1): 1-16.

Hallward-Driemeier, M. (2013). 'Enterprising Women: Expanding Economic Opportunities in Africa'. Washington, DC: World Bank and Agence Française de Développement (AFD).

Hasan, R., R. Afzal, and S. Parveen (2011). 'Motivational Orientation and Perceived Social Support among Pakistani Female Entrepreneurs in Attock District'. Journal of Gender and Social Issues, 10: $37-55$.

Hicks, J.H., M. Kremer, I. Mbiti, and E. Miguel (2011). 'Vocational Education Voucher Delivery and Labor Market Returns: A Randomized Evaluation among Kenyan Youth'. Report for 
Spanish Impact Evaluation Fund, Phase II. Washington, DC: World Bank. Available at: http:/ / documents.worldbank.org/curated/en/599701468047733808/Vocationaleducation-voucher-delivery-and-labor-market-returns-a-randomized-evaluation-amongKenyan-youth (accessed 3 September 2017).

Hundley, G. (2001). 'Why Women Earn Less Than Men in Self-Employment'. Journal of Labor Research, 22(4): 817-29.

ILO (2012). ‘Global Employment Trends for Women'. Geneva: ILO.

Kantis, H., P. Angelelli, and V.P. Koenig (2005). 'Developing Entrepreneurship: Experience in Latin America and Worldwide'. Washington, DC: Inter-American Development Bank/Fundes International.

Kantor, P. (2005). 'Determinants of Women's Microenterprise Success in Ahmedabad, India: Empowerment and Economics'. Feminist Economics, 11(3): 63-83.

Kevane, M., and B. Wydick (2001). 'Microenterprise Lending to Female Entrepreneurs: Sacrificing Economic Growth for Poverty Alleviation?'. World Development, 29(7): 1225-36.

Khwaja, A., and B. Klinger (ongoing). 'Psychometric Analysis of Entrepreneurs'. Cambridge, MA: Entrepreneurial Finance Lab, Harvard University.

Klapper, L., and S. Parker (2011)., 'Gender and the Business Environment for New Firm Creation’. World Bank Research Observer, 26(2): 237-57.

Mead, D.C., and C. Liedholm, (1998). 'The Dynamics of Micro and Small Enterprises in Developing countries'. World development, 26(1): 61-74.

Minniti M. (2010). 'Female Entrepreneurship and Economic Activity'. European Journal of Development Research, 22(3): 294-312.

Nichter, S., and L. Goldmark (2009). 'Small Firm Growth in Developing Countries'. World Development, 37(9): 1453-64.

Rauch, A., and M. Frese (2007). 'Let's Put the Person Back into Entrepreneurship Research: A Meta-Analysis on the Relationship between Business Owners' Personality Traits, Business Creation, and Success'. European Journal of Work and Organizational Psychology, 16(4): 353-85.

UBOS (2006). 'Uganda National Household Survey 2005/06'. Kampala: Uganda Bureau of Statistics.

United Nations (2014). ‘Guidelines for Producing Statistics on Violence against Women'. New York: UN Department of Economic and Social Affairs, Statistics Division.

World Bank (2011). 'World Development Report 2012: Gender Equality and Development'. Washington, DC: World Bank.

Yuan, K., J. Steedle, R. Shavelson, A. Alonzo, and M. Oppezzo (2006). 'Working Memory, Fluid Intelligence, and Science Learning'. Educational Research Review, 1: 83-98.

Zhao, H., and S.E. Seibert (2006). 'The Big Five Personality Dimensions and Entrepreneurial Status: A Meta-Analytical Review'. Journal of Applied Psychology, 91(2): 259-71. 


\section{Appendix}

Table A1: Summary statistics for female-owned enterprises-mixed-methods data set

\begin{tabular}{|c|c|c|c|c|c|}
\hline & Total & StDev & Crossover & Non-crossover & Difference \\
\hline \multicolumn{6}{|l|}{ 1. Personal characteristics } \\
\hline Age & 39 & 10 & 38 & 40 & -2 \\
\hline \multicolumn{6}{|l|}{ Father employment } \\
\hline Father worked on family farm & 11 & 31 & 11 & 10 & 1 \\
\hline Father owned or managed enterprise & 53 & 50 & 39 & 61 & $-22^{\star *}$ \\
\hline Father had pvt wage job & 23 & 42 & 20 & 25 & -4 \\
\hline Father had gvt wage job & 9 & 29 & 20 & 3 & $17^{\star \star \star}$ \\
\hline Father had other occupation & 4 & 19 & 9 & 1 & $8^{\star \star}$ \\
\hline \multicolumn{6}{|l|}{ Mother employment } \\
\hline Mother was a housewife & 26 & 44 & 36 & 21 & $15^{\star}$ \\
\hline Mother worked on farm & 25 & 43 & 30 & 22 & 7 \\
\hline Mother owned or managed enterprise & 41 & 49 & 23 & 51 & $-28^{\star \star \star}$ \\
\hline Mother had a wage job & 8 & 26 & 11 & 6 & 6 \\
\hline \multicolumn{6}{|l|}{ Marital status } \\
\hline Married or cohabiting & 52 & 50 & 57 & 49 & 7 \\
\hline Divorced & 22 & 41 & 14 & 26 & -12 \\
\hline Widowed & 18 & 39 & 16 & 19 & -3 \\
\hline Never married & 8 & 28 & 14 & 6 & 8 \\
\hline \multicolumn{6}{|l|}{ Religion } \\
\hline Protestant & 24 & 43 & 23 & 25 & -2 \\
\hline Muslim & 33 & 47 & 27 & 36 & -9 \\
\hline Pentacostal & 17 & 38 & 20 & 16 & 5 \\
\hline Catholic & 26 & 44 & 30 & 24 & 6 \\
\hline \multicolumn{6}{|l|}{ Region of birth } \\
\hline Kampala & 22 & 41 & 18 & 24 & -5 \\
\hline Eastern & 16 & 37 & 23 & 12 & 10 \\
\hline Central & 37 & 48 & 34 & 38 & -4 \\
\hline Western & 20 & 40 & 16 & 22 & -7 \\
\hline Northern & 4 & 19 & 9 & 1 & $8^{\star *}$ \\
\hline Foreign country & 2 & 12 & 0 & 2 & -2 \\
\hline \multicolumn{6}{|l|}{ Other characteristics } \\
\hline Ratio of male siblings & 0.9 & 0.7 & 0.8 & 0.9 & -0.1 \\
\hline Boy ratio, father-owned enterprise interaction & 0.4 & 0.7 & 0.2 & 0.5 & $-0.3^{\star *}$ \\
\hline \multicolumn{6}{|l|}{ 2. Skills and abilities } \\
\hline Raven's test score & 6.5 & 3.4 & 5.5 & 7.0 & $-1.6^{\star \star \star}$ \\
\hline Digit test score & 3.0 & 1.2 & 3.1 & 3.0 & 0.0 \\
\hline Locus of control aggregate score & 0.6 & 0.1 & 0.6 & 0.6 & 0.0 \\
\hline
\end{tabular}




\begin{tabular}{|c|c|c|c|c|c|}
\hline Agreeability score & 0.7 & 0.1 & 0.7 & 0.7 & -0.0 \\
\hline Emotional stability score & 0.7 & 0.1 & 0.7 & 0.7 & $-0.0^{\star \star \star}$ \\
\hline Conscientious & 0.8 & 0.1 & 0.8 & 0.8 & -0.0 \\
\hline Self-efficacy & 0.8 & 0.1 & 0.8 & 0.8 & 0.0 \\
\hline \multicolumn{6}{|l|}{ 3. Psychosocial factors } \\
\hline Male role model & 19 & 39 & 30 & 13 & $16^{\star *}$ \\
\hline First job in non-male sector & 78 & 41 & 52 & 91 & $-39^{\star \star \star}$ \\
\hline \multicolumn{6}{|l|}{ Exposure origination } \\
\hline Self-interested & 23 & 42 & 9 & 29 & $-20^{\star \star \star}$ \\
\hline Suggested to me & 23 & 42 & 32 & 18 & $14^{*}$ \\
\hline Employed in sector by relative & 21 & 41 & 36 & 13 & $23^{\star \star \star}$ \\
\hline Observed others & 12 & 33 & 16 & 10 & 6 \\
\hline Worked in sector for a stranger & 21 & 41 & 7 & 28 & $-21^{\star \star *}$ \\
\hline \multicolumn{6}{|l|}{ Exposure enabling factor } \\
\hline Self idea & 7 & 25 & 5 & 8 & -3 \\
\hline Someone's suggestion & 7 & 25 & 11 & 4 & 7 \\
\hline Observed others in sector & 7 & 25 & 9 & 6 & 3 \\
\hline Trained & 37 & 48 & 30 & 40 & -11 \\
\hline Employed in sector by relative & 20 & 40 & 36 & 12 & $24^{\star \star *}$ \\
\hline Worked for a wage in sector & 23 & 42 & 9 & 29 & $-20^{\star \star \star}$ \\
\hline \multicolumn{6}{|l|}{ 4. Capital } \\
\hline Years of education & 8.4 & 3.2 & 8.4 & 8.5 & -0.1 \\
\hline Owned enterprise in other sector & 30 & 46 & 36 & 27 & 9 \\
\hline Chose sector due to low capital & 10 & 30 & 7 & 11 & -4 \\
\hline Delayed start saving for capital & 23 & 42 & 27 & 21 & 6 \\
\hline Years of experience in past jobs & 9 & 10 & 6 & 10 & $-3^{*}$ \\
\hline Trained before starting business & 23 & 42 & 16 & 26 & -10 \\
\hline $\mathrm{N}$ & 133 & & 47 & 86 & \\
\hline
\end{tabular}

Notes: ${ }^{\star \star \star} p<0.01,{ }^{\star *} p<0.05,{ }^{*} p<0.1$.

Source: Authors' own construction. 